\title{
"How to Sustain National Security": A Case Study of the Celebrations of the Slovak National Uprising as a Securitization Platform
}

\author{
Vladimír Naxera *(D) and Petr Krčál \\ Department of Politics and International Relations, Faculty of Arts, University of West Bohemia, 30100 Pilsen, \\ Czech Republic; pkrcal@kap.zcu.cz \\ * Correspondence: vnaxera@kap.zcu.cz
}

Received: 7 October 2020; Accepted: 28 October 2020; Published: 30 October 2020

check for updates

\begin{abstract}
This paper focuses on the ways in which political actors make use of historical legacies to present their own determination to sustain their country's national security. We use the example of the annual celebrations of the anniversary of the Slovak National Uprising (SNU) to demonstrate the ways in which similar celebrations can become a platform for political actors to express requests and address their audience. Using semi-participant observation, we have analyzed six years of these celebrations (2015-2020) and the securitizing strategies and moral panic creation strategies contained in the speeches of participating politicians. Our analysis shows that securitization is taking place, and labels of threat sources are being given not only to topics that are naturally linked to the celebrated event, but also topics that are in no way related to SNU. Despite this fact, politicians use the legitimacy of the event to manifest their own attempts at sustaining security.
\end{abstract}

Keywords: securitization; moral panic; public ceremonies; use of history; sustainability of security; Slovak politics; Slovak National Uprising

\section{Introduction}

The issue of sustainability is discussed throughout the scientific field and throughout individual scientific disciplines from the natural to social sciences. In the latter, the issue has resounded in a whole number of approaches and research topics, from discussions on environmental sustainability to economic sustainability and the sustainability of the democratic nature of a given regime. Security studies (or critical security studies) are a specific field, as they deal with the ways in which politicians intend to "sustain security", often in reaction to the changing nature of the world. In this respect, "securitization", i.e., the labelling and naming of "threats", is a crucial concept. A vast number of approaches and tools are used for securitization, one of which may be references to the past (or political memory) while shifting it to contemporary political discussions (cf. Strukov and Apryshchenko 2018; Jutila 2015). This paper builds upon this discussion, i.e., the use of historical references in securitization processes in contemporary politics. The subject of our research is the use of the legacy of the Slovak National Uprising (further referred to as SNU) and the context of a significant political event, i.e., the annual celebrations of the SNU in Banská Bystrica during the security production of participating Slovak politicians.

SNU, which was the second largest anti-fascist uprising in all of Europe during the Second World War (just behind the Yugoslavian partisans) holds a strong position in Slovak national mythology (Miháliková 2005). Two main topics of the SNU, the relation to the pro-German Slovak State and the position of the Slovaks in Czechoslovakia, play a crucial role in the perception of the history of Slovak nationhood. The public opinion surveys realized after the fall of the communist regime 
conclude that the SNU is perceived as one of the most positive events of Slovak history and the central commemoration place in Banská Bystrica is one of the strongest symbols of the Slovak nation. Before its fall, the communist regime utilized the SNU legacy as well-the SNU was the most frequented topic of Slovak cinematography and has had priority in the sacral topography of many Slovak cities (Mannová 2008). The celebrations commemorating this event play an important political role, and have thus become a suitable platform for making political requests that are legitimized by the symbolism of the event, time and place (Alexander 2006, p. 61) (in general, the commemorations of occasions such as the SNU can be (and are) utilized as tools of the shaping of collective memory; see (Lehnerová 2017)). This includes requests to "sustain security", which is often a reaction to changes taking place in the international and global context (migration, terrorism, wars). The topic of the Second World War and the anti-German uprising in speeches given by political actors during the celebrations is often linked not only with the issue of Slovakia's security during the Second World War, but also with present security risks. This is the reason why a significant portion of many political speeches given during the celebrations includes the creation of moral panic (Cohen 2011; Goode and Ben-Yehudah 2009) or the securitization (see Buzan et al. 1997; Balzacq 2005) of various phenomena and actors who represent a source of danger in the ideas of the participating politicians. For this reason, the goal of this text is to identify the actors and phenomena presented by Slovak political representatives during SNU celebrations as a source of danger to the sustainability of Slovakia's security. At the same time, we try to capture the transformations surrounding the emphasis placed on individual sources of threats between 2015 and 2020. Over this time, we have carried out field research of these celebrations, and some particular arguments have already been published (Naxera and Krčál 2016; Naxera and Krčál 2017); the study is linked to the previous Czech-language version (see Naxera and Krčál 2020).

In order to capture the ways in which speakers construct the image of a threat, we use two concepts-if it is necessary to define certain phenomena as threats, the solution of which requires us to exceed the framework of standard politics, we label the whole process as securitization (Buzan et al. 1997). If the phenomenon is being portrayed as a source of threat and a subsequent political mobilization against this event is taking place, we label it as the creation of moral panic (Cohen 2011). This division stems from the speakers' qualitatively and quantitatively differing rhetorical strategies against the individual sources of threats, which are mutually incommensurable and thus difficult to grasp with only one concept. The two research questions of this text have been derived from this framework: (1) What phenomena/topics/actors are a subject of securitization or the creation of moral panic? (2) Which actors are involved in securitization/the creation of moral panic?

\section{Materials and Methods}

An appropriately framed past can be used as a justification for various political steps and decisions (Doucette 2018; Benazzo 2017). A politicized history is an integral part of politics in any type of regime, including established democracies. The importance of an appropriate and necessary perception of events (SNU in our case) plays an important role in national mythology. It creates specific cultural ideas and by doing so strengthens the existing political order, as this order is confirmed by references to an appropriately ordered past. The instrumental handling of history and the use of variously interpreted historical events is typical for all types of regimes and political actors.

The Slovak National Uprising, which was an attempt in 1944 to take a stance not only against Nazi Germany but also the pro-German regime in Slovakia (Kliment and Nakládal 1998), is framed as one of the foundations of the modern Slovak national mythology and an important milestone in the development of Slovak statehood (Mannová 2008). For this reason, the legacy of SNU is still an important theme today and resonates throughout Slovak society and politics. The day that commemorates the anniversary of the uprising is one of the central points of the Slovak political calendar, which is important for building and sustaining the identity of the nation and state. The uprising took place after the several-year existence of the Slovak State, which was an ally of Nazi Germany. Although the topic of SNU is still quite lively in contemporary politics, references to the existence 
of the Slovak State are less frequent. The question of collective forgetting is thus strongly present in Slovakia (Michela 2008, p. 9). Although we can find a dominant positive interpretation of SNU in contemporary Slovak politics, there are streams of thought that understand SNU as an illegitimate uprising against the first "sovereign" Slovak state in history.

The scene of the central celebrations of SNU's anniversary is the area of the SNU Museum in Banská Bystrica, which serves as the central and physical site of collective memory (Norra 1989) linked to the celebrated event. Objects in public space, e.g., this museum and the victims' memorial (Verdery 1999) that forms a part of it, serve as a tool to commemorate historical events linked to the constitutive points of national mythology. These sites reproduce significances that are often abstract (victory, nation, and homeland) but have a strong emotional charge (Oláh 2013, p. 730). The emotional appeal and symbolism are therefore highly utilizable in political speeches, which often take place on these sites on various occasions. This context makes it possible to play a certain role in the processes of securitization. Here we use the assumption made by Balzacq (2005), who claims that in order for the process of securitization to be effective, it is necessary to link it to a certain context and direct it towards addressing a specific audience. The use of the symbolism of a date, place and event in the framework of public celebrations provides a platform that fulfills the aforementioned attributes for the securitizing actors and fosters rhetoric leading to the demonstration of "sustainable security".

\subsection{Theoretical Framework: Moral Panic vs. Securitization}

In order to analyze the ways in which the construction of threat sources takes place during the central celebrations of SNU's anniversary in Banská Bystrica, we have chosen two theoretical approaches-the theory of securitization and the theory of moral panic. We perceive securitization in the way in which it is discussed in the Copenhagen school, i.e., as the creation of a source of threat linked to the attempt to implement measures that exceed the framework of standard political measures. We use three basic analytical units in agreement with this approach: (1) a referential object, i.e., an actor/phenomenon that represents the object of securitization; (2) a securitizing actor, i.e., the person who creates and frames a threat via the use of specific rhetorical constructions; and (3) actors who are not securitizing actors but play an important role in securitization (Buzan et al. 1997).

In order to label an actor as securitizing, his/her argumentation towards a reference object must be directed towards the attempt at a solution that exceeds the framework of standard politics or towards what Agamben calls a "state of exception". This is a solution that, aside from exceeding the standard framework of politics, calls for a solution that transcends the system of law (Agamben 2005, p. 26). If some actors/phenomena are portrayed as threats but the aforementioned securitization strategies do not take place, they will be treated as objects of moral panic. Moral panic is characteristic for its (re)production of stigmatizing attributes that lead to the perception of objects of moral panic as sources of (vaguely or specifically denoted) danger (Cohen 2011). The division of analyzed phenomena into reference objects and objects of moral panic makes it possible to analyze what topics/actors are securitized and what topics/actors are only portrayed/or as a threat source. In addition, this division will allow us to provide an interpretation of the specific ways in which securitization takes place via the use of public events as platforms. The last reason for this analytical division is the fact that it allows us to identify securitizing actors and the strategies they use.

\subsection{Research Materials (Field Research 2015-2020)}

The central celebrations of SNU's anniversary, which take place annually on the day of the beginning of the uprising (29 August), which is also a national holiday, are a significant political event with the participation of a score of state representatives, foreign guests and political representatives from all levels of Slovak politics. In addition to the symbolism of the event's date, celebrations also take place in a significant place (Alexander 2006, p. 61). Banská Bystrica was the center of the uprising, and the celebrations take place in close proximity of the building of the SNU Museum. Although the events take place over the course of several days, the primary political event takes place in the form of 
a several-hour-long cycle of speeches and commemorative acts. The anniversary of the celebrations began to be celebrated after WWII, and the celebrations took on different connotations in different periods, primarily connotations of reproduced meanings and not necessarily of the celebrations themselves. After the fall of communist regime, the content of the celebrations was changed in relation to the newly installed ideological order, e.g., the dominant narrative ceased to be dominated by the emphasis on the Soviet aid to the uprising; on the contrary, the uprising began to be framed as part of the European and democratic tradition of Slovak statehood (Michela 2014, p. 5). The form and structure of the celebrations change frequently, however, the main narratives of the SNU celebrations have remained the same from the fall of the communist regime till today-the legitimization of the Slovak nationhood in the European context (and the topics that were analyzed by us fits in this framework well) (Mannová 2019, p. 187). Moreover, they are related to the issues connected to the phenomenon of security, which plays a crucial role in politics (Ušiak 2018). We can point out that the SNU celebrations represent a suitable research terrain that can be compared to other similar occasions across Europe.

The whole act (including the accompanying program consisting of concerts or presentation of historical military technology) is of a similar character and structure each year and consists of a commemorative act (wreath-laying at the monument), an introductory speech by the host (i.e., the director of the SNU Museum), and speeches by present state representatives. Each year, appearances are made by the president, prime minister and chairman of the National Council (i.e., the Slovak Parliament). During the six-year research, changes have taken place in all of these posts, which, to a certain degree, manifests itself in the structure and content of the speeches given. The position of president has been held by Andrej Kiska (2015-2018) and Zuzana Čaputová (2019-2020); position of prime minister by Robert Fico (2015-2017), Peter Pellegrini (2018-2019) and Igor Matovič (2020); and position of chairman of the National Council by Peter Pellegrini (2015), Andrej Danko (2016-2019) and Boris Kollár (2020). Apart from these aforementioned state representatives, the event is annually attended by representatives of local and regional governments, although not in the position of speakers. One exception is the former head of the regional self-government of the Banská Bystrica Region, present members of parliament, and chairman of the People's Party Our Slovakia (LSNS) Marian Kotleba, who has neo-Nazi tendencies (Maškarinec 2018). A part of this party's program is the adoration of the Slovak State (and its president Jozef Tiso) and the refusal of SNU, which it claims to have been a putsch against a legitimate government, and its legacy in today's politics. In addition to refusing to attend the ceremony, Kotleba demonstrated his dismissive attitude by hanging a black flag from the windows of his regional office. During the celebrations in 2016, for example, his absence was commented on by one organizer of the event in the following manner: "I don't suppose I have to explain why the head of the regional self-government isn't here; even so, I couldn't help making the comment". As we will point out below, Kotleba and his relationship to both history and contemporary political preferences became the topic of speeches during the celebrations in 2017, which took place before the Slovak regional elections, during which Kotleba planned to defend his mandate.

\subsection{Methodology}

We observed these celebrations over the course of six consecutive years (2015-2020). Research took place in the form of semi-participant observation and by recording the form and content of events into research notes. Semi-participant observation was implemented according to the following scheme: (1) we covered the whole space that was later to become our research terrain in advance, (2) we took strategic positions in order to observe both speeches given on the stage and interactions from the audience, (3) we individually wrote down the findings into research notes, and (4) we then wrote down the gathered data together into a final field diary, which contains the most accurate possible records of content (including verbatim quotations from the speeches) and the form of the observed event. The year 2020 was an exception, as it was not possible to make the research trip due to limitations caused by the state of the pandemic; this year was therefore analyzed via media representations of the event, specifically via television broadcast of the ceremonial portion of the whole event. The fact 
that the whole event was broadcast live by public television emphasizes the importance and symbolic nature of the whole event.

We then worked with the recorded and transcribed speeches as we would with any other text and processed the data via inductive content analysis. During manual coding, we focused on issues that were framed as sources of danger (either in the sense of securitization or the creation of moral panic). We focused primarily on actors of securitization/creation of moral panic and the reference objects of this effort. The third variable, i.e., indirect actors, is the same in all cases-the direct audience (present on the spot) and the indirect audience (consumers of the television broadcast and other media messages covering this event) (Musilová 2014).

During the several-year-long research, one dominant theme (i.e., the reference object in our sense) was observed in certain years of the celebrations and found throughout individual speeches from the mouths of politicians, who made up an ideologically and politically heterogenous group. The majority of topics, which we will deal with in more detail below, is linked with security or the issue of sustaining it. It was also possible to observe different levels of emphasis placed on the given problem and reflected in differentiating securitization and the creation of moral panic. The celebrations in 2015 were strongly influenced by the so-called migration crisis, and the topic of migration therefore resonated as a central motif; the legacy of SNU was used to take a stance against migrants coming from Europe. The celebrations of 2016 were dominated by Slovakia's both negatively and positively interpreted relationship with Russia and the EU. The following year was influenced by ongoing elections to regional governments and the strong stance of political actors against the head of the regional self-government of the time, Kotleba, or in general against the phenomenon of (neo-)Nazism and (neo-)fascism (however, references aimed at Kotleba were strong in 2015 and 2016 as well). This issue, i.e., taking a stance against right-wing extremism, seems natural in the context of the celebrations of an anti-fascist uprising. The celebrations of 2018 lacked a dominant theme, and speeches in this year were also held in a less confrontational spirit in terms of portraying threats of danger to Slovakia than in prior years. We can say the same for 2019, although in this case (although not to such a degree as in 2017), we can find a stance against present extremism. The same can be said for 2020. In this year, several references to the threat of COVID-19 were made, although more implicitly than explicitly.

As we have already stated, the third unit of the securitization process, i.e., the creation of moral panic, which consists of indirect actors, remains outside the framework of our interest, as they are the same in all cases. Their role was passive in the observed events and stemmed from the fact that they were the recipients of the performed utterances (directly or via the media). For our research, other variables were relevant-these include the actors of securitization/creation of moral panic (i.e., participating politicians—-see above), but primarily also reference objects (i.e., presented sources of danger) that are projected into the structure of the coding tree. Individual sub-codes portraying the essence of the source of danger were allocated to each reference object (i.e., code). The method of coding is shown in the table below (see Table 1). Although analysis took place based on codes and sub-codes, the following sections are structured in the following manner: each section deals with one code, i.e., of reference objects; however, the section is not ordered inwardly according to sub-codes, but according to actors of securitization/creation of moral panic and celebration years-the goal of this is to record a potential transformation in the rhetoric of individual actors over the course of time.

Table 1. The code structure.

\begin{tabular}{ccc}
\hline Right-Wing Extremism & Migration & Selected Actors of European Politics \\
\hline Physical threat & Economic threat & \\
Threat to state power & Physical threat & Russia as a threat \\
Threat to democracy & Threat to democracy & The EU as a threat \\
Threat to identity & Threat to identity & \\
\hline
\end{tabular}


Methodological note: verbatim quotes listed below are taken from interviews during the celebrations. It is evident from the quote who made the speech and in what year; therefore, we have not included a link in the interest of the text's fluidity.

\section{Analysis and Results}

\subsection{Right-Wing Extremism}

It is logical to start with the topic of Nazism and fascism as threats to Slovakia, as the SNU was led against the regime of the Slovak State and its subjugation to Nazi Germany. Celebrations of SNU's anniversary are therefore led in the spirit of anti-Nazism and anti-fascism, not only in relation to the historical events of the Second World War, but also to the Slovak political party system. Slovakia has had an almost constant experience with the presence of extreme-right parties in its parliament since the fall of communism. The Slovak National Party, long led by Ján Slota, has almost always been a part of the parliament (with the exception of 2002-2006 and 2010-2012) (see Kluknavská and Smolík 2016) and in some cases was the ruling party. However, in 2016, the extreme-right scene took on a new dimension thanks to the parliamentary success of the neo-Nazi People's Party Our Slovakia linked to Marian Kotleba. The success of this party is based on changes within the Slovak party system (Hynčica 2019). In 2013, Kotleba won the second round of the election for head of the regional self-government of the Banská Bystrica Region (Buček and Plešivčák 2017; Mikuš et al. 2016), and his party gained more than $8 \%$ of the vote in 2016, giving them a total of 14 mandates in the Slovak Parliament. The celebrations that took place a year later significantly reacted not only to Kotleba's year-old parliamentary success, but also to the upcoming local government elections in 2017. References focusing on the danger that Kotleba and (neo-)Nazism and (neo-)fascism in general pose had already appeared earlier.

The basis of the majority of speeches throughout individual years is the adoration of SNU, the explicit stance against fascism and Nazism, and the explicit or implicit stance against the Slovak State as the bearer of this ideology. Similar statements could be found among all speakers. At the same time, reference to WWII, fallen partisan heroes, and speeches of the oft-mentioned self-sacrifice of the Slovak nation are shifted from the past to the present and used within the contemporary political struggle.

In 2015, speeches on a general level were aimed against the threat of Nazism, while Marian Kotleba was not explicitly mentioned. These references (of which there were less in comparison to the following years) were focused not only on the protection of the legacy of SNU, on which doubt was being cast by the extreme right, but also on the social danger of the existence of an extreme right. For example, the chairman of the National Council Peter Pellegrini said the following during the 2015 celebrations: "We cannot allow the toleration of Nazis. We cannot agree to guards marching through our streets, beating people up". By saying this, he thus framed the (neo-)Nazis as a source of direct physical threat to the population.

A far more vehement appeal against the extreme right resounded in 2016 after Kotleba's success in parliament elections, although Kotleba was not directly mentioned in this year but rather through certain allusions. The situation was expressed succinctly by Pavel Sečkář, chairman of the Slovak Union of Anti-Fascist Fighters: "After the elections for parliament, the shaved heads that were giving the Nazi salute in the streets are now lounging in the benches of parliament". In his speech, President Andrej Kiska also touched upon the topic as he searched for political parallels between the time of the uprising and the present: participants in the uprising overcame political, ideological and religious differences and agreed that freedom and racial and religious equality are the more important values. According to Kiska, these values also apply to contemporary Slovak society and it is important to actively defend them. It is not possible to associate oneself with the legacy of SNU and at the same time tolerate the idea that SNU was a "stain" on Slovak history. We can consider this to be a clear stance against Kotleba's perception of SNU and the Slovak State. Robert Fico also spoke in a similar spirit when, 
in reaction to election results, he expressed his dissatisfaction with the fact that a number of political entities had chosen hatred as their program.

In relation to stances against (neo-)Nazism and (neo-)fascism, doubtlessly the most interesting celebrations took place in 2017, shortly before elections to regional government and the realistic threat that Kotleba would defend his mandate and leadership of the region. President Kiska's speech contained a strong anti-Kotleba message: "It is not enough to commemorate and make speeches while the posthumous sons of fascism are roaming the streets. When a fascist won, it was a shock for Banská Bystrica. When he entered the parliament, it was an even greater shock. We are trying to come to terms with this and react to the fascists. What hatred is hidden behind their smiles and green shirts. Their only contribution to the public debate has been the spread of hatred. They know how to intimidate and bully; they do not know how to administer public affairs". He also framed the topic in the context of the upcoming regional elections: "We will stand up to evil and drive the fascists out of the Banská Bystrica Region. Kotleba sees the beginning of SNU as the darkest day in Slovak history, and his only contribution has been to spread hatred. Region by region, we must not give up our beautiful country to fascists. We do not have to fight with weapons in our hands, and we do not have to be heroes. It is enough to be true citizens, participate in democratic elections and choose a non-fascist candidate. There are more of us and we can defeat them, and we can draw courage from those who stood up to evil in incomparably worse conditions." During this appeal, he deftly instrumentalized the past-taking part in elections at present and voting against fascists is a certain analogy to the anti-fascist struggle of the participants in SNU.

Mobilization rhetoric was also used by the chairman of the Slovak National Party and chairman of the National Council Andrej Danko, who called upon voters to "remove the Nazis from the region". Prime Minister Fico, who linked the current threat of (neo-)Nazism with the legacy of the Slovak State, spoke in a similar spirit: "[We all know] what Slovakia looked like at the time when the Slovak State existed as one of Hitler's underlings. Life was calm here, but Nazis and guard members were walking around, and Slovaks were participating. And next door [to the site of the celebrations] is a building that is once again being called "Na stráž" [a salute used during the Slovak State by Slovak Nazis, that can be translated as "On guard"], and we have the feeling that this is ok. [... ] Freedom of speech doesn't mean giving the Nazi salute, chanting "Na stráž", and so forth. I am calling upon law enforcement to take action".

The celebrations of 2018 took place in a much less confrontational spirit. Clear reference to Kotleba was made again by Pellegrini, who called voters of the extreme right, who were doubting the legacy of SNU, people who had no respect for history and belonged in the "ash heap of history". At the same time, he thanked residents of the region for coming together in the 2017 elections and creating a "small SNU" by driving out Kotleba from his function as the head of the region and thus protecting the legacy of SNU. In 2019, however, a stronger warning of the threat of present extremism could be observed. Andrej Danko claimed that it was a disgrace that "people who are distorting history, putting on fascist uniforms and enjoying the trust of citizens are in politics" and by doing so implicitly referred to Kotleba's party. Prime Minister Pellegrini also took a stance against far-right extremism, pointing out propaganda and calls for violence that were spread via social networks. He pointed to the trend of transforming and reducing extremist rhetoric - at present, right-wing extremists are hiding behind values of conservatism and traditionalism. In 2020, several mentions were made of subduing contemporary extremism with regard to showing respect for fallen fighters and participants in SNU.

Present right-wing extremism was thus framed across years and actors as a security risk in various regards (Buzan et al. 1997). Firstly, it is a physical threat to the population, which was explicitly mentioned in analyzed speeches ("guards marching through our streets, beating people up"). In these words, the speakers were pointing to the phenomenon of creating paramilitary groups that are symptomatic of this form of extremism. However, this does not necessarily entail paramilitary units such as the Czech National Militia or the Hungarian Guard Movement; in the Slovak political context, they may be embodied in a distinctly more banal example-groups of LSNS members in party t-shirts who decided voluntarily to patrol Slovak trains. By doing so, they also disrupted the authority of the state's institutions, as they attempted to break the Weberian monopoly of state power to carry out 
physical violence and justice. At the same time, right-wing extremism is presented as a threat to the democratic order and the constitutionality of the Slovak state. As Slovak political identity is seen as anti-fascist in individual speeches thanks to the legacy of SNU, contemporary right-wing extremism is also understood as a danger to the nation's identity.

Despite the fact that fascism and Nazism (or right-wing extremism) are portrayed by a number of speakers as a threat (and a relatively fundamental one targeting different aspects of the operation of the state and society), they are not a reference object of the process of securitization, as calls for action exceeding the framework of standard politics are not taking place (Buzan et al. 1997). On the contrary, the dominant and requested solution presented by individual actors was linked to a call for standard democratic procedures, primarily the need to come together in elections and defeat the extremists. On the other hand, such framing of extremism fully corresponds to the creation of moral panic (Cohen 2011). The phenomenon of right-wing extremism was one of the most frequented topics that can be explained by several arguments. Firstly, the participating actors perceived the right-wing extremism as a most imminent threat to the sustainability of security in Slovakia. Secondly, this was amplified by the situation with (neo-)Nazi politician Kotleba mentioned above. Thirdly, the creating of moral panic around right-wing extremism suits well the general framework created around the SNU legacy narrative. The avoidance of securitization of right-wing extremism and creating moral panic around it can serve as an illustration that the participating actors were asserting standard political countermeasures (unlike the topic of migration; see below).

\subsection{Migration}

The topic of migration tends to be a frequent subject of securitization (Bourbeau 2011; Krotký 2019), and the context of Slovak politics is not an exception (Androvičová 2015). Negative references about migrants within Slovak politics were strongly evident before elections in 2016, but the fundamental breaking point had already come in the summer of 2015 (Žúborová and Borárosová 2017, p. 10), when both a worsening in the media's picture of refugeeism and the strengthening of negative statements on the part of politicians, primarily Prime Minister Robert Fico, could be observed. Slovakia mostly avoided the wave of migration, which was reflected in the vague statements made by politicians shortly after the so-called migration crisis broke out. These statements were mostly in the line of "it's the EU's problem, not Slovakia's". In 2015 and 2016, however, a "defensive discourse" appeared, framing migration as a security threat for Slovakia. This manifested itself in a change in the Smer party's primary slogan, which shifted from its original "Smer works for Slovakia" to "Smer is protecting Slovakia" (Žúborová and Borárosová 2017, p. 8). Fico, head of the Smer party, was the most respected politician speaking about migration in the media at the time. The negative framing of migrants became the political mainstream, while President Kiska was an exception. Prime Minister Fico went the farthest in saying that the secret service should monitor all Muslims on Slovakia's territory (Žúborová and Borárosová 2017).

In regard to the fact that existing research placed the breaking point for the negative framing of migration in the summer of 2015, this approach manifested itself in the SNU celebrations in the same year. It is also interesting that, with the exception of occasional mention, the topic did not appear in speeches in other years (2016-2020). In 2015, however, almost all speakers (although in different ways) expressed their views concerning migration, and migration became the central theme of the celebrations. Robert Fico profiled himself as the fiercest opponent of migration, which corresponds to the aforementioned research (Žúborová and Borárosová 2017).

Fico devoted a significant portion of his speech to the topic of migration, beginning with SNU, continuing on about the security threat posed by immigrants, and returning to SNU. According to Fico, fascism was a threat that Slovakia stood up to thanks to SNU—now there is a new threat-the threat of migration-and it is necessary for Slovakia to stand up to this threat too and not to disappoint SNU's legacy. In the prime minister's words, the situation of refugees is regrettable, but "we", i.e., Slovaks and Europeans in general, must also be protected. Therefore, it is not possible to risk European security 
in order to save refugees. The creation of this "us" (Slovaks, Europeans) versus "them" (migrants) dichotomy can be seen as a basic categorization in the narrative of (in)security; at the same time, it is one of the basic categories of populist strategy (Knight 1998, p. 223). As Fico went on: "Let's not pretend that we don't see the people's fear. They are afraid, not only in Slovakia, but in all of Europe. Let's not pretend that we don't see the causes of this phenomenon, and let's not pretend that we're able to solve this problem by welcoming everyone with open arms, regardless of whether they're economic schemers or people who need protection for their lives, health and family". In Fico's words, Slovakia did not take part in the bombing of Syria or Libya and thus did not take part in their destabilization. Therefore, he cannot be reprimanded for not helping refugees, as he does not carry the blame for the state that their homes are now in. Although it is necessary to differentiate between individuals who are arriving because of finances and individuals who are fleeing war, Slovakia is not required to help either group. Fico took a stance against the local opponents of this opinion as "pseudo-humanists welcoming refugees". "Europe is facing an uncontrolled influx of refugees from various parts of the world. European politics has completely failed in terms of migration, [ . . uncontrolled] immigration can destroy Slovakia and Europe [ ... ], Let us be honest-we're not able to integrate our own Roma citizens, of which there are hundreds of thousands. How can we integrate people who are in a completely different place in terms of their life and religion? [ ... ] If the idea of quotas reappears, we will once again refuse it". He added that Christians are able to integrate, which is, however, in contradiction with his previous statement about problems with integrating Romas, who by vast majority are Roman Catholic. In his conclusion, Fico shifted from migration and returned to SNU, deftly utilizing its legacy: "We must protect traditions, values and democracy, and if we can't protect them sufficiently from immigrants, elections will be won by fascists and Nazis, who will take on this problem in a completely different way. The people whom the Slovak National Uprising was lead against would win". The other speakers either dealt with migration only marginally, from a different perspective, or not at all.

It is possible to say that the securitization issues identified by the analysis do not represent the dominant broad shared discourse of the SNU celebrations narrative. On the other hand, we can highlight the fact that the main securitizing actor was Prime Minister Robert Fico. Since the phenomenon of migration was securitized mainly by the prime minister, the relevance of it remains intact (despite the fact that the securitization of migration does not stand as a leitmotif of the SNU celebrations narrative. If we take a closer look at the framing of migration by Robert Fico, we can see it as a securitized phenomenon, which is evident both from the intensity of the given threat's portrayal and the repertoire of suggested solutions exceeding standard politics (e.g., the idea that the secret services should monitor all Muslims in Slovakia) and legal norms (the refusal of quotas to redistribute migrants exceeds legal norms on an EU level). The threat to Slovakia by migration is evident on several levels-the first is an economic threat (i.e., "economic migrants" who will harm the state's economy via their presence), threats stemming from a "threat to culture or social cohesion" (Czajka 2014; Mukhin 2015; Lægard 2010) due to cultural differentness and the impossibility of integrating (alleged) newcomers, and of course a physical threat ("migrants are potential terrorists"). The last line of endangerment can strengthen extremist tendencies in society ("if we aren't against migration, people will vote for Kotleba").

\subsection{Russia and the European Union}

The last reference objects that we will deal with are the significant players in European politics (and beyond), i.e., the EU and Russia, and the relationship between Slovakia's security and these actors. We have decided to include the EU and Russia into one chapter, as the speeches of the analyzed actors (primarily Robert Fico, who gave this topic, just like migration, the most attention) frequently contained negative framing of one actor and the positive framing of another. The topic of the EU and Russia was emphasized most strongly in 2015 and 2016, primarily in relation to the so-called migration crisis, and also the EU's attitude towards Russia. 
In his speech in 2015, chairman of the National Council Pellegrini defined three significant security threats that Europe and Slovakia must take into consideration-Russian foreign policy activities, war in Ukraine, and migration. However, he did not specify in greater detail how exactly they represent a threat, how to deal with it, etc. Russia, however, is clearly labelled a threat source (even a two-fold threat, as Russia is also the actor of war in the Ukraine).

Fico spoke in much more detail about the security connotations of Slovakia's relationship towards the EU and Russia. "The Slovak National Uprising is a pearl that people of every nation and state would be proud of. This pearl allows us to speak the truth". According to Fico, one of these truths is that Czechoslovakia was sold out by the West in Munich. By saying this, he began his stance against the West, which continued throughout his whole speech and culminated in criticism of the EU in connection with its migration policy and the danger that migrants are said to pose to the EU: "Europe is facing an uncontrolled influx of migrants from various parts of the world. European politics has completely failed in terms of migration [... I If the idea of quotas reappears, we will once again refuse it". He added to this stance against the EU by claiming to be aware of the fact that there were numerous representatives of European countries in the audience who, as he hoped, would pass on the message to their governments and to Brussels. Uncontrolled "immigration can destroy Slovakia and Europe". Therefore, no one can force upon anyone else the obligatory acceptance of refugees. "The country has the right to choose who they want to accept and in what number". Thus, in Fico's words, the EU's policy clearly presents a risk for the sustainability of Slovakia's security, primarily due to migration policy, but also due to escalations in relations with Russia.

In 2016, Fico made a symbolic connection to his previous speech to a certain degree when he claimed he was worried that some representatives of Slovak and European policy are looking for an enemy to whom they could pass on all their problems. He emphasized that he was refusing any antipathy in Russian-Slovak affairs and the pinning of causes of all problems on Russia. At the same time, it was clear in his speech that the figure framing Russia in such a way was the European Union. Fico also warned of a possible escalation of conflict between Europe and Russia (explicitly mentioning former British Prime Minister May, who admitted her willingness to use nuclear weapons if necessary). The Soviet Union took the lion's share of defeating Nazism, and it is not possible to make an enemy out of Russia. Robert Fico was thus the only speaker in 2015 (rather implicitly) and 2016 (strongly explicitly) to defend an alliance with Russia on one hand and take a stance against the EU on the other.

If we summarize the relationship of both speakers towards both these actors of European politics and their framing as a threat, we find two narratives. The first is the labelling of Russia as an unspecified threat, and the second is the EU labelled as a threat by Robert Fico. The reason for viewing the EU in this manner is its migration policy. The EU is thus an actor that indirectly threatens Slovakia by supporting a direct source of Slovakia's endangerment, i.e., migration, which is securitized by Fico in his following speeches. At the same time, we cannot claim that Robert Fico has made the EU into an object of securitization; however, his argumentation does fulfill the attributes of the creation of moral panic. Pellegrini's labelling of Russia as a threat was a brief and vague statement without implications, and, therefore, we can consider it to be neither moral panic nor securitization. As you can see above, the speeches related to the EU and Russia are marginal in comparison to the speeches related to the right-wing extremism and migration. Nevertheless, the EU and Russia were mentioned by two state representatives holding crucial functions within the political system-we decided to mention this for completeness.

\section{Discussion and Conclusions}

In the following sections of this text, we have focused on four reference objects that were mentioned in relation to SNU anniversary celebrations in connection with the sustainability of Slovakia's security and framed by the legacy of SNU—-these include (right-wing) extremism, migration, Russia and the EU. In all cases, these are themes that are fundamental for contemporary European politics (of both European countries individually and the EU as a whole). At least in the context of V4 countries, 
we can observe the success of the extreme right (although with differing intensity among countries) (Kazharsky 2017); strong anti-migration stances of a significant portion of the political representation and in some cases the regime as such (Kalmar 2018); criticism of European politics (Kaniok and Havlík 2016); and a swing on the part of the political representation towards Russia (Benazzo 2017). The majority of these topics is also linked with the ongoing discussion on the possible decline of liberal democracy in Central Europe (Bustikova and Guasti 2017).

As we have already stated, Slovakia was not able to avoid the success of the extreme right on a parliamentary level. Other actors on the Slovak political scene reacted to Marian Kotleba's success by taking a strong stance against the extreme right or creating moral panic from it. At the same time, however, this was not the securitization of the extreme right, as the tools called for by the speakers to be aimed at the extreme right did not exceed the framework of standard politics, and quite the contrary is true. The extreme right was mentioned in terms of the observed SNU anniversary celebrations across individual years and speakers. Pointing to the problematic nature and the danger of (neo-)Nazism and (neo-)fascism is not only a matter of SNU anniversary celebrations-it is a wider political phenomenon. However, the argument against the extreme right expressed during the celebrations can rely on the symbolism of the place, time and event (Alexander 2006, p. 61). Thus, historical legacy is used to support current political demands, which are directly linked to this legacy in terms of the construction of moral panic concerning (neo-)Nazism and (neo-)fascism. On the other hand, it was possible to identify situations in which the legacy of SNU was instrumentalized by the speaker to support political demands that had no connection with the celebrated event. An example of this is Robert Fico, who took the position of the "only securitizer" throughout the various years, using the legacy of SNU to securitize migration (and create moral panic against the European Union), which he put in direct connection with this legacy. The other speakers across the years spoke of the sustainability of Slovakia's security to a much lesser degree (with the exception of right-wing extremism), speaking about it only occasionally and without more detailed argumentation. The results are summarized in the Table 2 below.

Table 2. The results.

\begin{tabular}{cccc}
\hline & $\begin{array}{c}\text { Right-Wing } \\
\text { Extremism }\end{array}$ & Migration & $\begin{array}{c}\text { Selected Actors of } \\
\text { European Politics }\end{array}$ \\
\hline Securitization/Moral panic & Moral panic & Securitization & $\begin{array}{c}\text { EU-moral panic/ } \\
\text { Russia-xxx }\end{array}$ \\
Securitizing actor (only in the case of securitization) & $\mathrm{xxx}$ & Robert Fico & Xxx \\
Link to the celebrated historical event & YES & NO & NO \\
\hline
\end{tabular}

The example of Robert Fico thus precisely demonstrates the use of a de facto unconnected historical legacy to securitize migration. The role of this legacy in Slovakia's national mythology, which it helps to sustain throughout the generations, is so significant that it allows for the creation of a platform used by politicians to manifest their willingness to maintain the country's security (but realistically only manifesting their own political vision without regard to its (dis)connection with the celebrated event). When seeing our results and conclusions in a broader context, we can say that the theories of securitization/moral panic are relevant frameworks to analyze the construction of security narratives during public occasions. We show that public political ceremonies can be used as instruments that serve as platforms for the creation of security narratives. And, of course, it is not the only case in Slovakia (and the SNU celebrations). Our paper can be seen as a contribution to the wider debate about the use of history in contemporary politics.

Author Contributions: Both authors worked on all parts of the paper. All authors have read and agreed to the published version of the manuscript.

Funding: This research was funded by the Czech Science Foundation under grant 'Instrumental Politicization of History as a Legitimization Tool of Political Regimes' (18-08605S).

Conflicts of Interest: The authors declare no conflict of interest. 


\section{References}

Agamben, Giorgio. 2005. State of Exception. Chicago: Chicago University Press.

Alexander, Jeffrey Charles. 2006. Cultural pragmatics: Social performance between ritual and strategy. In Social Performance: Symbolic Action, Cultural Pragmatics. Edited by Jeffrey Charles Alexander, Bernd Giesen and Jason Mast. New York: Cambridge University Press, pp. 29-90.

Androvičová, Jarmila. 2015. Sekuritizácia migrantov na Slovensku-analýza diskurzu. Sociológia 47: 319-39.

Balzacq, Thierry. 2005. The Three Faces of Securitization: Political Agency, Audience and Context. European Journal of International Relations 11: 171-201. [CrossRef]

Benazzo, Simone. 2017. Not All the Past needs To Be Used: Features of Fidesz's Politics of Memory. Journal of Nationalism, Memory \& Language Politics 11: 198-221.

Bourbeau, Philippe. 2011. The Securitization of Migration. A Study of Movement and Order. London: Routledge.

Buček, Ján, and Martin Plešivčák. 2017. Self-government, development and political extremism at the regional level: A case study from the Banská Bystrica region in Slovakia. Sociológia 49: 599-635.

Bustikova, Lenka, and Petra Guasti. 2017. The Illiberal Turn or Swerve in Central Europe? Politics and Governance 5: 166-76. [CrossRef]

Buzan, Barry, Jaap de Wilde, and Ole Wæver. 1997. Security: A New Framework for Analysis. Boulder: Lynne Rienner Publishers.

Cohen, Stanley. 2011. Folk Devils and Moral Panics. In The Creation of the Mods and Rockers. Oxon: Routledge.

Czajka, Agnes. 2014. Migration in the Age of Nation-State: Migrants, Refugees, and the National Order of Things. Alternatives 39: 151-63. [CrossRef]

Doucette, Siobhan. 2018. The uses of history by the Polish democratic opposition in the late 1970s. Nationalitics Papers 46: 151-63. [CrossRef]

Goode, Erich, and Nahman Ben-Yehudah. 2009. Moral Panics. In The Social Construction of Deviance. Oxford: Blackwell.

Hynčica, Pavel. 2019. Krize a kontinuita "starých" a nástup nových politických stran na Slovensku. Central European Journal of Politics 5: 55-70.

Jutila, Matti. 2015. Securitization, history, and identity: Some conceptual clarifications and examples from politics of Finnish war history. Nationalities Papers 43: 927-43. [CrossRef]

Kalmar, Ivan. 2018. "The battlefield is in Brussels": Islamophobia in the Visegrád Four in its global context. Patterns of Prejudice 52: 406-19. [CrossRef]

Kaniok, Petr, and Vlastimil Havlík. 2016. Populism and Euroscepticism in the Czech Republic: Meeting Friends or Passing By? Romanian Journal of European Affairs 16: 20-35.

Kazharsky, Aliaksei. 2017. The End of Central Europe? The Rise of the Radical Right and the Contestation of Identities in Slovakia and the Visegrad Four. Geopolitics 23: 754-80. [CrossRef]

Kliment, Charles, and Břetislav Nakládal. 1998. Germany's First Ally: Armed Forces of the Slovak State 1939-1945. Atgles: Schiffer Publishing Ltd.

Kluknavská, Alena, and Josef Smolík. 2016. We hate them all? Issue adaptation of extreme right parties in Slovakia 1993-2016. Communist and Post-Communist Studies 49: 335-44. [CrossRef]

Knight, Alan. 1998. Populism and Neo-populism in Latin America, Especially Mexico. Journal of Latin American Studies 30: 223-48. [CrossRef]

Krotký, Jan. 2019. When Migration Unites Political Parties: The Securitisation of migration in Czech Party Manifestos. Politologickýž časopis 26: 181-99. [CrossRef]

Lægard, Sune. 2010. Immigration, Social Cohesion, and Naturalization. Ethnicities 10: 452-69. [CrossRef]

Lehnerová, Markéta. 2017. Manipulace s kolektivní pamětí na příkladu osvobození Rokycan. Acta Fakulty filozofické Západočeské univerzity v Plzni 9: 31-53.

Mannová, Elena. 2008. Piruety v inscenování minulosti. Slovenské národní povstání v proměnách času. Dějiny a současnost 8: 37-40.

Mannová, Elena. 2019. Minulost' ako Supermarket? Bratislava: VEDA.

Maškarinec, Pavel. 2018. Strategic Voting in Slovak Regional Elections of 2013 and 2017: Evidence for Duverger's Law in Elections of Presidents of Regional Self-Government? Sociológia 50: 697-726. [CrossRef]

Michela, Miroslav. 2008. Pripomínanie a kanonizovanie minulosti. Úvaha na margo niektorých diskusií o dejinách Slovenska. Forum Historiae 2: 1-13. 
Michela, M. 2014. Oslavovaní a zatracovaní. Povstalci a oslavy SNP ako predmet oficiálného pripominania protifašistického odboja. 2014. Available online: http://www.moderni-dejiny.cz/clanek/clovek-ve-valce-avalka-v-cloveku-slovenske-zamysleni/ (accessed on 30 September 2020).

Miháliková, Silvia. 2005. Sviatky na Slovensku ako súčast’ politických rituálov. Historický časopis 53: 339-54.

Mikuš, Roman, Daniel Gurňák, and Anna Máriássyová. 2016. Analýza volebnej podpory Mariána Kotlebu ako reprezentanta krajnej pravice v krajských vol'bách 2013. Sociológia 48: 48-70.

Mukhin, Yevhen. 2015. Cultural Security of Slovakia in the Context of the Integration of the Slovak Republic in the EU. Politické vedy 18: 66-87.

Musilová, Martina. 2014. Teatralita veřejných události-uvedení do problematiky. Theatralia 17: 9-24.

Naxera, Vladimír, and Petr Krčál. 2016. The Slovak National Uprising as a national Treasure? Interpretation and Legacy of the SNU in Slovak Political Discourse and National Mythology. Annual of Language E Politics and Politics of Identity 10: 83-102.

Naxera, Vladimír, and Petr Krčál. 2017. Perceptions of Slovak Politicians and their Discursive Reification at the Clebrations of the Slovak National Uprising in 2016. Studia Politica. Romanian Political Science Review 17: 279-94.

Naxera, Vladimír, and Petr Krčál. 2020. Oslavy výročí Slovenského národního povstání jako platforma pro vytváření obrazů nepřátel Slovenska. Czech Journal of International Relations 55: 5-20. [CrossRef]

Norra, Pierre. 1989. Between Memory and History: Les Lieux de Mémoire. Representations 26: 7-24.

Oláh, Gábor. 2013. Kolektivní pamět', proctor a významy. Případ náměstí Svobody v Budapešti. Sociologický časopis 49: 729-50.

Strukov, Vlad, and Victor Apryshchenko. 2018. Memory and Securitization in Contemporary Europe. London: Palgrave Macmillan.

Ušiak, Jaroslav. 2018. Slovakia's perspective on NATO. Communist and Post-Communist Studies 51: 125-37. [CrossRef]

Verdery, Katherine. 1999. The Political Lives of Dead Bodies. Reburial and Postsocialism Change. New York: Columbia Universitsy Press.

Žúborová, Viera, and Ingrid Borárosová. 2017. Migration Discourse in Slovak Politics. Context and Content of Migration in Political Discourse: European Values versus Campaign Rhetoric. Journal of Nationalism, Memory E Language Politics 11: 1-19.

Publisher's Note: MDPI stays neutral with regard to jurisdictional claims in published maps and institutional affiliations.

(C) 2020 by the authors. Licensee MDPI, Basel, Switzerland. This article is an open access article distributed under the terms and conditions of the Creative Commons Attribution (CC BY) license (http://creativecommons.org/licenses/by/4.0/). 